\title{
Spiritual Capital and Social Welfare in Indonesia
}

\author{
Budi Mulianto \\ Faculty of Social and Politics \\ Islamic University of Riau \\ Pekanbaru, Indonesia \\ budi.ip@soc.uir.ac.id
}

\author{
Risky Setiawan \\ Faculty of Social and Politics \\ Islamic University of Riau \\ Pekanbaru, Indonesia
}

\begin{abstract}
This study analyzes the link between spiritual capital and social welfare in Indonesia. One of them i.e. spiritual capital is the Foundation for the political and cultural social life contained in the ideology of Pancasila. And social welfare is one of the conditions to which it was for the creation of social functioning in the life of the compound. Using the study of literature in the secondary for the next load of data in the analysis. It is achieved that spiritual capital is the doctrine that has been embedded in each individual society of Indonesia. Are all essential in the manifestation or against social welfare implications of doctrine is done by the individual or group who has the power of the spiritual definition of the capital against other individuals. So the spiritual capital and the interconnectedness of the social welfare community is very strong.
\end{abstract}

\section{Keywords - Spiritual Capital; Social Welfare}

\section{I. INTRODUCTION}

Indonesia with the concept of ideology that loosely ideology pancasila, has a grounding in the social life of politics and culture to set its community. The cornerstone of this as a rigid value should hold and does not conflict with other values. The ideology of Pancasila as the basic countries Indonesia contains grains of (1) the divinity of the one true God; (2) a just and Civilized Humanity; (3) the unity of Indonesia; (4) led by Populist Wisdoms in Consultative and representative; (5) social justice for all the people of Indonesia.

The first Sila divinity of the one true God as the Foundation of monumental for the sustainability of the social life of the politics and culture of the nation of Indonesia gave its own meaning if viewed as an entity in the cultural diversity of the people of Indonesia. This is caused by the diversity was so prominent in the community but must value the Godhead soldered Almighty God as the Foundation of a philosophical and practical.

The divinity of the one true God intimately connected with all trust or confidence that should be mandatory and embraced by the people of Indonesia who inhabit the region of Indonesia in order to be achieved a life of plenary. Thus the embodiment of these values are completely manifest by the individual nations of Indonesia with a choice of belief or faith. In essence, these values have been rigid and mandatory individual soul, held by Indonesia.

To describe the followers of belief or trust in Indonesia in the manifestation of religion or belief, the data presented in the following Central Bureau of statistics of the Republic of Indonesia with Indonesia population category based on the religions recognized in Indonesia. [1]

TABLE 1.

The number and percentage of Population according to Religious beliefs of the year 2010

\begin{tabular}{|l|r|r|}
\hline Religion & $\begin{array}{c}\text { The Number Of } \\
\text { Residents }\end{array}$ & $\begin{array}{c}\text { The percentage } \\
\text { of }\end{array}$ \\
\hline Islam & 207176162 & 87.18 \\
\hline Christian & 16528513 & 6.96 \\
\hline Catholic & 6907873 & 2.91 \\
\hline The Hindu & 4012116 & 1.69 \\
\hline Budha & 1703254 & 0.72 \\
\hline Kong hu cu & 117091 & 0.05 \\
\hline Other & 299617 & 0.13 \\
\hline Not Answered & 139582 & 0.06 \\
\hline Not asked & 757118 & 0.32 \\
\hline The total number of & $\mathbf{2 3 7 ~ 6 4 1 ~ 3 2 6}$ & $\mathbf{1 0 0}$ \\
\hline
\end{tabular}

To the diversity of the above, we can only see the diversity through differences of belief or faith that bound through religion. While according to the Zohar that "spiritual is Spiritual capital is the amount of spiritual knowledge and expertise available to an individual or a culture, where the spiritual is taken to mean" meaning, values, and fundamental purpose"[2]. This means that in addition to religious belief, there is also included in the spiritual beliefs pervading what-what is believed by the estranged individual entities within the tribe, race, class, the cantonal Parliament keeping the trust as a spiritual capital for individuals who believe. The purpose of the doctrine is the attainment of self of an individual against a things into his goal in life, i.e. welfare.

Social welfare is a great achievement in the conditions of human life as a whole in each of his joints include the condition of social, spiritual and material. The condition requires a thorough effort to acquire it includes efforts that championed individually or the efforts made by individuals, small groups or organized groups through activities of 
intervention against the conditions the lives of others. Country Indonesia enshrine social security terminology in LegislationLaw No.11 years 2009 about social welfare, article 1 paragraph 1 refers to the condition of meeting needs material, spiritual and social life in order to be citizens deserve and be able to develop themselves, so that it can carry out its social function. [3]

View of the symptoms above, then this study concerns the orientation of spiritual values embraced by the public social welfare achievement against Indonesia. How spiritual capital is the basis of the achievement of a sense of well-being for every individual in Indonesia? How is the manifestation of a sense of social welfare based on the spiritual capital is in Indonesia?

\section{RESEARCH METHOD}

This article uses the method kualitatatif as an approach with the study of literature and the type eksplanatif. Discuss one topic with the approach of the libraries to compile overall information about the topics covered include references to books, articles, government documents, documents, websites, Research Institute for further diinterpretasi. With the scope of the study that analyzed was about the relationship between the spiritual capital and the achievement of individual and social well-being of the people of indonesia.

\section{RESULT AND DISCUSSION}

\section{A. Spiritual Capital}

Understanding spiritual capital according to the Roosevelt Malloch:

I define the spiritual capital of the U.S. "the fund of beliefs, examples and commitments that are transmitted from generation to generation through a religious tradition, and which attach people to the transcendental source of human happiness ". Amplifying this, I think: we are moral beings, in all the ways that Adam Smith describes. But we are also spiritual beings. We seek out the source of our transcendental values. We join with others in acts of worship and prayer. Through spiritual discipline, habit and exercise, we absorb the legacy of spiritual knowledge that is contained in a religious tradition. [4]

Spiritualitas is sourced from religiosity, which it has value as a handle to say as a person or society that holds spiritual. As it was said Hardjana:

With the portrayal of spirituality, religious people become spiritual people, namely people who embody the spirit of God in accordance with real everyday life calls and the role of his life. He absorbs the entire spiritual values and directs himself as well as his life based on the values of spirituality and created a lifestyle and behavior according to the spiritual values of it. In religion, the spiritual person appreciation understood dogma, worship, runs carrying out moral and religious institutions make differently and in a higher level than people who just run religion. [5]

In understanding the explanation above, that the values of that spirituality is a dogma, worship and adoration and became a moral role model in carrying out one's familiarity with the manifest in the attitude and behavior. Dogma is the starting point of a servant in the get to know God, practiced everything that was ordered with a strong belief against the ingrained enough replies for any level of the command and any restrictions are violated. Worship is the manifestation of devotion by an individual upon conviction and the backrest of each activity in human life in the world with just hope to God. It is the fruit of moral beliefs and acts of worship are taught to religion in order to correspond between the deities with virtue.

\section{B. Spiritual Capital in the definition of the nation of Indonesia}

In the definition of the nation of Indonesia, spiritual capital is the fruit of a professed religious beliefs of each individual. Indonesia strongly believes that it is the basic foundation for spiritual exclusively for each individual and generally against one nation and a country life in achieving prosperity. This is set forth in the Temple of the opening of the 1945 Constitution:

"Top of the blessings of God Almighty and impelled by the desire of the sublime, that the non-national ones, then the people of Indonesia declared independence."

The basic foundation of welfare in the form of manifestation of the independence that has been achieved is the grace of the Almighty God. Independence was granted to the people of Indonesia that aims to promote the "general welfare". From this editorial then the definition of spiritual capital as capital base in the social life of Indonesian politics and culture is the most important thing.

With recognized and thrust of religious belief and confidence has also been mounting position of the spiritual capital as a diversity that is appreciated by the State to further the existence of religion are arranged in any interactions. With the high esteem the great day against any religious, Indonesia has given a very wide space for any religions to achieve obedience which is essential in the relationship between God and his adherents.

Therefore, Indonesia as a country with a diversity of religions indicates the definition of religion is a very important existence for every element in the social life of politics and culture.

\section{Social Welfare}

Conceptually, social welfare has several meanings, as revealed by Midgley that " a state or condition of human welbeing that exist when social problems are managed, when 
human needs are met, and when social opportunities are maximized". [6]

This indicates that social problems can be managed with good then social welfare is achieved. The condition of social welfare achievements can be done with social intervention. Social welfare is also a condition experienced by an individual or the community spiritually.

The meaning of welfare achievement collectively is also based on the spiritual capital as capital in social development. ADI stated that:

"Spiritual capital, role in social development, development and empowerment of the community includes several functions, among others:

1. Improving the work ethic and give a thrust or spirit ( $a$ drive) which is positive in the construction;

2. Give the soul in an attempt grant;

3. Provide direction in development; and

4. Be a ' guardian ' (protector) against irregularities.

The function of being a patron of things diverged for Indonesian people in particular is crucial, because the behavior of the existing diverge in the country this has reached a level that endangers not only bring up the behavior of corruption, but it also gave rise to conditions in which occurs the obscurity of norms and values in society. [7]

\section{The spiritual Doctrine in achieving social welfare in Indonesia}

Intervention efforts against other people's living conditions is based on the attribute by anything that has been embedded in nature's thought that individual. If in her spiritual doctrine is embedded, then the individual will automatically refer to the people who have the ability to cultivate a spiritual matter which has existed in him. This will take place very easy for an offender interventions. Perpetrator intervention only adds to the confidence in the achievement of the conditions of social welfare through spiritual cultivation.

Achieving prosperity through religious dimension covers the whole joints of human life Indonesia. Indonesia as a country with a diversity of religious understanding has been conducting institutional arrangement against the religion embraced by every individual in Indonesia, namely:

a. Islam: Assembly of Indonesia scholars (MUI)

b. Christian: Fellowship of churches of Indonesia (PGI)

c. Proposedk: Episcopal Conference of Indonesia (KWI)

d. Hinduism: Parisada Hindu Dharma Indonesia (PHDI)

e. Buddhism: Buddhist Representative Indonesia (Walubi)

f. Confucianism: Confucianism Councillors Indonesia (Matakin)

All of the above agencies organize the religious life for all believers still. The functions of the agency include: a. As a guide to life

b. sources of truth

c. Regulatory procedures for relations between fellow human beings and human beings with God

d. The requirement of the principle of right and wrong

e. Guidelines for the disclosure of feelings of fraternity in a religion are obliged to do good against your fellow man.

f. Guidelines human beliefs do good deeds should always be accompanied by a belief that his actions were an obligation from God and am sure it will get the reward of his deeds, though the slightest deeds.

g. Guidelines for the Existence in fact of living things in the world is God's creation.

h. Disclosure of human aesthetic value feelings tend to be fond of beauty because beauty is part of the human psyche.

i. The guidelines create a recreation and entertainment. In search of contentment through recreation and entertainment, does not violate the norms of the religion.

With the above function, then the control against the spiritual capital of Indonesian people is not contaminated by the teachings and values other than the religious setting of institutionalized.

\section{E. Manifestations of social welfare based on Spiritual Capital in Indonesia}

There are many cases that occur in Indonesia as a manifestation of the embodiment of social welfare based on spiritual capital, both of which are false or in fact gives the impact of happiness for every individual. A comparison of both of these things can be given some examples among others;

\section{(1) Social welfare based on the spiritual capital that is false}

Social welfare is obtained by an individual with believes the confidence attributes and symbolizing religion and media doctrinization by an individual or group. The manifestation of this is undoubtedly in the achievement of social welfare which seems to have an affinity with the spiritual capital is the phenomenon of the presence of His personal Abiding Dimas, as summarized by the Dharma that the emergence of the belief from individuals and look objectively in the eyes is the fruit of doctrization through verbal communication so that it appears the conviction of any person.

"Objectivity is subjectivity that featured actual personal Abiding processed in well-established and persuasive. The actions of communication abilities Personal Abiding refers to the process of rhetoric and persuasion are being made to play on the psychological level of his followers to profitable Personal Abiding unilaterally or in the cencus. Moreover, emerging social construction over the image of the Devout, especially through a number of social attributes attached to himself so the more Devout way 
strengthens the Personal in her community in the eyes of Imaging. "[8]

Dissemination of belief a person against that figure on behalf of religion as a cornerstone achievement of prosperity became a legitimate social construction. Teachings like this only satisfies the mind space of any people who adopt them due to exploit individuals who have the welfare orientation material. While social welfare achievement meant never materialized, then each individual get the impact of frustrating against the search for spiritual substantial capital Foundation.

(2) Social welfare based on the spiritual capital that is essential to

The spiritual capital that is essential to be able to guide people in the achievement of social welfare. Due to the Foundation of the spiritual capital is derived from religion and not concerned with the symbolism of the attributes, but in the realization of welfare activities collectively. Spiritual capital substantial scattered and embedded deeply in the individual because of not just doctrinization but has a figure that can be imitated in plenary.

The teachings of the spiritual capital base that is essential to have a value attached to each individual and not oriented in social conditions and the weakening of the material. Spiritual substantial capital in Indonesia institutionalized in any recognized religions in Indonesia. In this example the loaded about religious teachings of Islam which has a collective spiritual values in the achievement of social welfare. The manifestation of the teachings of Islam in Indonesia as the Foundation of social welfare achievements have values that are not different because Islam is a religion of universal enclosing each human life by not unbounded region State.

In Islam, as revealed by Canda \& Furman in his book Spiritual Diversity in Social Work Practice, the Heart of Helping quoted in Adi, States about Islam that have a human approach in social reform to achieve a prosperous stage in the life of the world and the hereafter, that:

"Because of the individual and the community should be oriented to achieve the pleasure of ALLAH, there is no separation between religious life and the life of the world ... As the Prophet Muhammad taught Muslims to do social reform based on the interests of women, children, and groups of less advantaged. In Islam there is a very strong emphasis on the value of the social justice framework. Ideally, it should be created by a relationship of reciprocity between the complementary individual liberty with duty tawab and from the community. The Qur'an condemns acts of exploitation on the poor, widows, women, orphans, and slaves. The Quran also denounces the abuse of the 'power ' of the economy, as do the false contracts, bribery, property and usury stack ". [9]

Values that are essential to understanding of the spiritual against capital built in the Islamic religion is as the embodiment of the deity are built to cope with diversity in social politics and culture. Through this spiritual values becoming a cornerstone in the achievement of social welfare for all believers and have an impact in the social life of the community as a whole.

\section{CONCLUSION}

A. That spiritual capital is the doctrine that has been embedded in each individual society of Indonesia. The cultivation of the spiritual capital of the individual against society's ideology pancasila Indonesia dimaktubkan that requires every individual to embrace one religion as the identity of the individual. Next the doctrine of the faith and trust of the religious doctrines or disseminated through other diinterpretasi doctrine by individuals or other groups to influence other individuals with attributes or symbolizing religion.

B. Manifesitas of social welfare are pseudo or true depending on the implications of the doktrinisasi carried out by individuals or groups that have the power of the spiritual definition of the capital against other individuals. Spiritual capital is undoubtedly in the achievement of social welfare is obtained by an individual with believes the confidence attributes and symbolizing religion and media doktrinisasi by an individual or group. An essential spiritual manifestation is the spiritual capital that scattered and embedded deeply in the individual because of not just doktrinisasi but has a figure that can be imitated in plenary

\section{References}

[1] [1] Indonesia, b. p. s. r. (2011). Nationality, ethnic origin, religion, Language and Everyday residents of Indonesia: the results of the population census 2010 , p. 10

[2] [2] Zohar, d., \& Marshall, i. (2004). Spiritual capital: Wealth we can live by. Berrett-Koehler Publishers. p, 27

[3] [3] Undang-Undang Republic Indonesia No.mor 11 years 2009 about social welfare, article 1 paragraph 1

[4] [4] Roosevelt Malloch, t. (2010). Spiritual capital and practical wisdom. Journal of Management Development, 29(7/8), 755759. pp, 756

[5] [5] Hardjana, a. m. (2005). Religiosity, religion, and spirituality. Canisius. p, 65

[6] [6] Midgley, j. (1997). Social welfare in a global context. Sage, p. 5

[7] [7] Adi, Isbandi Rukminto . (2013) . Community development and Community intervention (As community empowerment Efforts). Jakarta: PT Raja Grafindo Persada, p. 264

[8] [8] Dharma, f. a. (2017). DIALECTIC SOMETIMES INTRAPERSONAL COMMUNICATION: EXAMINING THE CHARM OF COMMUNICATION WITH YOURSELF. al-Balagh Charity and communication: journal, 2 (1), 25-44, pp. 42

[9] [9] Adi, Isbandi Rukminto. (2013) social welfare (social work, social development and Development Studies). Jakarta: PT Raja Grafindo Persada, p. 8 